\title{
圈 \\ Analyzing the Impact of Demonetization on the Indian Stock Market: Sectoral Evidence using GARCH Model
}

\author{
Patil Anoop ${ }^{1}$, Parab Narayan ${ }^{2}$ and Y. V. Reddy ${ }^{3}$
}

\begin{abstract}
On $8^{\text {th }}$ November 2016, the Government of India demonetized its two highest currency notes in the denomination of Rs. 500 and Rs. 1000. The purpose of demonetization was to tackle the corruption and black money prevailing in the country. The stock market is one of the areas which pools a large amount of funds, the present study is an analytical attempt to examine the impact of demonetization on Indian stock market. For the purpose of the study, various statistical techniques have been used such as Graphical Analysis, Summary Statistics (i.e. Mean, Standard Deviation, Skewness, and Kurtosis), Augmented Dickey-Fuller Test and GARCH Model. The study utilizes the GARCH model to examine the impact of demonetization on Nifty 50 Index and across sectoral indices in India considering a period of 200 days prior and post event date by framing necessary dummy variables. The study found the data to be stationary using the Augmented Dickey-Fuller Test. A significant negative impact of demonetization on stock market returns was evidenced from Nifty 50 Index and sectoral indices such as Nifty Auto Index, Nifty Financial Services Index, Nifty FMCG Index, Nifty IT Index, Nifty Media Index, Nifty Private Bank Index, and Nifty Realty Index. The study found the Nifty Realty Index to be affected most because of demonetization. The results of the study will help the Governing bodies to examine the impact of demonetization and frame necessary policies. The results will also be useful for investors and other market participants for framing investment and trading strategies.
\end{abstract}

JEL Classification: G10, G20.

Keywords: Demonetization, Stock Market Returns, Sectoral Indices, Demonetisation, GARCH.

\footnotetext{
${ }^{1}$ PG Student, Narayan Zantye College of Commerce, Bicholim, Goa, 403529, India. Email ID: anooppatil96@gmail.com

${ }^{2}$ Research Scholar, Department of Commerce, Goa University, Goa 403206, India. Email ID: parabnarayan9@gmail.com

${ }^{3}$ Corresponding Author, Registrar, Goa University, and Professor, Department of Commerce (on lien), Goa University, Goa 403206, India.

Email ID: yvreddy@unigoa.ac.in
} 
Patil, Parab \& Reddy | the Impact of Demonetization on the Indian Stock Market

\section{Introduction:}

Demonetization is a process of eliminating old currency and replacement by new notes and coins. On $8^{\text {th }}$ November 2016, Government of India demonetized its two highest currency notes in the denomination of Rs. 500 and Rs. 1000. The purpose of demonetization was to tackle the corruption and black money prevailing in the country. Primarily, demonetization acquired the procedure of replacing existing money with new one. Intensely, governments have drawn-out the determinations of demonetizing local money to report the threats of the underground economy of black cash, corruption, and imitation currency from the market. The key objective behind demonetization was to create India cashless and eradicate black money. Demonetization had a huge effect on the Indian market and citizens. People went to banks to do conversation of old currency with fresh currency and standing in lines in banks and ATMs to withdraw money. The new currencies had different characteristics with respect to size and width and thus needed re-adjustment of ATMs. The government also set a limit on banks \& ATMs for daily withdrawal of money. Although the decision of demonetization was a surprise for the entire nation, the government seemed to be preparing for it for a couple of months. The government took few steps much before demonetization which includes generation of bank accounts through Jan Dhan Yojana (PMJDY). The demonetization is expected to bring structural differences in the longer run and leading to a better reinforcement of the current economy.

Abda (2017) emphasized about the change of demonetization reserved by Indian Government on 8th November 2016 with respect to its causes and impact on different areas in India. The areas cover Micro Businesses, E-Wallet businesses, online retail stores and so on. Demonetization was measured with some benefits and drawbacks in several areas in the short run but in long run, it positively will have a helpful impact in monitoring black currency and fake currency. Apart from helpful benefits, it made some problem to poor divisions of the people. We also find Sinnarkar (2017) presented a study wherein the researcher revealed how demonetization impact on banking and monetary system in India. The Prime Minister conducted a war beside black currency by removing legal tender currency notes. The rushing risk of fake cash, especially in large denominations, cannot be stressed enough. India remained the outcome of demonetization will be a drop in credit development. Improvements for the banking structure are predictable to develop at 10-11 percent in FY17. Now, credit could expand at a slower speed of 5-6 percent. Credit off revenue has previously slowed considerably in the present financial year compared to FY16. Banks distributed Rs 89,500 crores from April to early December - down from Rs 4,03,220 crores in an identical period in 2015-16, agreeing to RBI data.

In the short run, could easily recognize its consequence on the economy, from the above conversation it was pure that the decision taken will have far-reaching influence on the economy (Abda 2017). The present study will evaluate the impact of demonetization on Indian stock market and also seek to evaluate such impact on various sectoral indices in India. For this purpose, the study develops the following hypotheses.

H0: There exists no significant impact of demonetization on Indian stock market 


\section{Review of Literature:}

Demonetization was one of the most historic decisions in Indian Economy. The decision which surprised the entire nation also attracted many researchers. After demonetization, many researchers attempted to examine the demonetization and its impact on Indian Economy. The presents study analyses the existing literature in 3 categories; namely, Demonetization- A General Perspective, Demonetization and Banking Sector, and Demonetization and Indian Economy.

\section{Demonetization- A General Perspective:}

Chelladurai \& Sornaganesh (2016) studied the influence of demonetization on Indian Business Environment. Citizens of India faced a lot of challenges due to demonetization. Government decision of demonetization was to reduce black money thereby and reduction in terror funding with false currency notes. It was a sign from the government to create cashless India as well as use technology. The application of demonetization would have been better if printing of sufficient cash and modification of ATMs was facilitated with efficiency. Jaiswal \& Jagtap (2017) described the several economic changes and the possible consequences of demonetization on various sectors. This study helps in determining the helpful and harmful consequences of note ban decision taken by the Indian government. The study was based only on secondary information, which was taken from newspapers, magazines, internet websites, some related books linked to the subject. The government recent decision to eliminate black currency in India was a big step in showing high-value currency. Demonetization decision affected the common public; however, it was unavoidable in such decisions in concern of the country. Also, it cannot entirely prevent black money, but definitely there was a big impact on breaking large quantities of black money.

Going cashless is one theme government focused post demonetization. Singh \& Singh (2016) highlighted in their study that India has the highest level of cash inflow at $12.1 \%$ of GDP. Money in hand was probably at around 3.2\% of domestic resources. $87 \%$ was form 500 Rs \& 1,000 Rs notes or approximately Rs 14 lakh crore. A major share of the national money in hand is created by monetary transactions that remain uninformed to tax specialists or from corruption. Scrapping the complex denomination currency would also affect these being taken into the structure or the currency just vanishing. This paper highlights the possible significances of this judgment on various monetary variables and entities. If the cash vanishes, the economy will not value. And if the cash finds its approach in the economy it could have a significant effect. But practices from various countries displays that the change remained single of the series that unsuccessful to answer a debt-hampered and inflationridden economy.

Nerkar (2016) found that brave step was taken by the government of India of demonetization of great worth currency denominations notes. Demonetization of money means the cutoff of some cash from the money flow and exchanging it with new cash. It takes extremely crushed Indian economy in several ways. However, it has been broadly commended as a helpful decision taken for the advantage of the citizens. This paper hints the influence of this move on Indian economy. Demonetization alone cannot make India match similar economies in 
terms of removing black currency. Some other processes are necessary for the Indian government to change the economy for the better. We should respect and support this move and wait with the tolerance for healthier implementation. Each Indian citizen should be responsible for part of our nation-building. And our temporary money issues are minor as related to the outcome in future. We should inspire and join together for the task of India development. Betz, Anderson \& Puthanpura (2017) elaborated the fiscal event of unexpected demonetization 2016-17 in India can offer a practical sample in which to exam the rationality of various schools of fiscal theory, mainly the Chartalist Institute.

The Chartalist Institute distinguished three classes of currency namely Fiat, Commodity, and Managed Cash. The occasion provided a practical sign that this difference between money now an economy was legal and significant. The unexpected removal of Fiat cash immediately reduced the expanse of commodity change, forming an economic disaster in local Indian exchange. Managed cash, as bank interpretations, was incapable to plug the impermanent break in the resource of cash because a huge share of the Indian residents did not require bank interpretations. As well the administration did not supply enough quantity of new 500 and 2000 Rs. notes to rapidly exchange the reserved 500 and 1000 Rs. notes. Dharmapala \& Khanna (2017) conducted a study and reveals how the stock market reaction to demonetization in India.

The specified motive for sudden demonetization was to battle tax avoidance and corruption. This study figure irregular earnings for organizations on the Indian stock market nearby this occasion, and link patterns of irregular earnings for altered subsamples of organizations defined by business, possession structure, and other features. There was a slight sign that areas thought to be associated with more tax avoidance or corruption skilled meaningfully different yields. The study finds helpful incomes for banks and state-owned enterprises, suggesting market expectations that are confusing in some compliments. Besides find outline of greater returns for businesses that are considered by a better requirement on outside finance, possibly advising hope of an enabling of economic limitations.

\section{Demonetization and the Banking Sector:}

As demonetization involved the exchange of old currency notes with the new ones, one sector which witnessed huge inflow of cash deposits in the banking sector. Jain (2017) observed that the demonetization is one sector probable totally benefited from this involvement was the banking area. The two areas of the banking area- private and public area banks have seen different trends in managing of non-performing assets ensuing in the recapitalization of public area banks by the government. This study observes the influence of demonetization on the returns of 40 listed banks in India. The study implemented an event study approach and regression methodology. The outcomes recommend that the overall banking sector had recorded a modest rise in returns after demonetization but the effect was short-lived. By segmenting the sector hooked on public and private segments reflect differential impacts. The public area banks witnessed an immediate positive result on the returns whereas the private banks recorded a lagged negative impact. Kanakalatha (2017) conducted the study to designate the modifications that are trending in Indian Banking and connected to managing cash part as the influence of demonetization. In demanding to elements which may reason for the never-before-seen modification, this study increases the pros and cons of money demonetization in altered banking areas. 
Data was collected over surveys that were mailed available to a number of individuals in Hyderabad. Individuals in the study finished the survey \& packed out a distinct permissionlinked form. Individuals who replied have selections in a diversity of sections, including Banking, Finance, Capital Markets, and Insurance areas. Individuals who replied were from a range of Institutions from both private and public organizations, the bulk being study oriented. Secondary information is collected from Internet and Newspapers. Specialists say that it was a good change as it will bring more formal money in the area. Gupta (2017) tried to recognize the problems tackled by restricted in retrieving banking services and if sufficient arrangements were complete for the restricted during the demonetization stage. The recent stage of the government of Indian to bit the money notes of Rs. 1000 \& Rs.500 as a permitted tender on November $8^{\text {th }}, 2016$ had an enormous influence on Indian masses. 50 Scheduled banks were plotted for the study and banking officers from several public banks along with private banks were also questioned.

\section{Demonetization and the Indian Economy:}

Rao \& Kotian (2017) made an attempt to know the outcome of demonetization of uppervalue currency notes on the running of Indian economy. This study also observes the consequence of demonetization happening GDP of India. Demonetization of currency in India has a significant role to play in the Indian economy as the effects caused by the demonetization-driven cash crisis that was singing out in India paralyze economic activity only in the short period and has a dynamic and important role towards the upliftment of economy. It will definitely bring structural modifications in the longer run and main to a greater formalization of the modern economy. Singh \& Panwar (2017) illustrated in their research on the present economic sensation in India and reflected as the base of extreme economic improvements. This paper studies the likely influence of demonetization on the casual economy of India along with the prospects and concerns of Indian economy. In this viewpoint, few problems need to be occupied care off like will demonetization develop the recognized economy and analyst the informal one? How will it touch the comfortable credit market? What actions are required to restrain the black budget other than demonetization? Will digitalization benefit online spending and marketing businesses? It also temporarily explains little programs of present government. The discussion in this study delineates the development as to how demonetization is a circumstance of growing strategy? Thus this paper considers demonetization conclusion as a strategic conclusion.

Samuel \& Saxena (2017) studied the short-period and long-period influences of demonetization with mention to the different divisions of Indian economy. It also deliberates whether demonetization will be involved in removing the black currency from Indian economy which is the key objective after currency switch. It is measured to have concentrated the country's GDP, undesirably hit the cash severe sectors, certain divisions of the nation namely agriculture area, small merchants, domestic are facing short-time disturbances due to lack of liquid cash etc. Besides corrupt applies, running of weapons, the stock of black currency will decrease etc. It can be assumed that demonetization determination creates cash crisis and liquidity crisis causing a problem to the overall public in short-time, but its resolution is shown to be helpful to the budget in long run on aspects like government income, the rise in credit, little interest charges on mortgages, and decay in inflationary force. Sivankutty (2017) highlighted the consequence of demonetization 
proceeding GDP and the involvement of different areas in GDP. By an opinion to restrain capital of terrorism and actions such as surveillance, running of weapons, drugs \& extra illegal imports to India and removing black currency, it has been definite to cancel the authorized tender charm of great denomination notes of Rs. 500 \& Rs. 1000 values issued by RBI. At the opening there raised a negative influence on the numerous areas of the budget which caused lesser growth. Reports from numerous sources through the country recommend that every area and districts have adversely exaggerated. Separately from all this information later at the finale of this fiscal year, the country displayed a growth of $7.1 \%$. This paper explains the influence of such a transfer on the GDP and study of some data's in a systematic method.

Bhatnagar (2017) studied the influence of demonetization in India. The word demonetization was not fresh to the Indian economy. The maximum denomination note constantly published by RBI was the 10,000 Rs note in 1938 and over in 1954. Then these notes stood demonetized happening January 1946 and once more in January 1978, giving to RBI records. On 8 Nov. 2016, the cash is demonetized $3^{\text {rd }}$ time by the current Modi supervision. This was the brave step engaged by the government for the improvement of the budget and nation. The change was directed towards confronting black currency, corruption, and terrorism. This paper studies the implication of denomination and the past of denomination in India. Further, the paper will center on the belongings of demonetization on the altered area of the Indian economy in detail. Bhausaheb (2017) stressed on the subject of the influence of demonetization happened Indian Economy. The dispute imagined now favour of demonetization was that the money that would be doused would be "black currency" and hence, must be fairly doused to regular accurate the willful incentive organization in the economy. While the details are not obtainable to anyone, it would be irrational to dispute that this was the only prospect. So, it is commanding to estimate the short outing and mediumduration effects that such a tremor is expected to ensure on the economy. Further, the influence of such modification would differ depending on the grade to which the administration agrees to remonetize. This paper clarifies the effect of such modification on the disposal of credit, spending, level of action and government funds. Pradeep (2017) examines the promptness of Indian economy to become cashless \& its suggestions in future. Demonetization only effects narrow money \& leaves the major component of the money supply; the broad money wide open, which if left unchecked would leave the issues as it is. In this case, the transition towards the cashless society proves to be a good way of achieving economic welfare. Although the rewards of a cashless culture are numerous \& have the potential to become one such society, some hurdles need to be crossed before we can enjoy all its welfares.

The review of the literature shows that a considerable amount of research has been done on the theoretical aspect of demonetization, but less contribution is given to the practical aspect. The present study breaches this gap and critically tests the impact of demonetization on Indian Stock Market by considering sectoral evidence using GARCH Model. The study has been conducted on the Nifty 50 index and 10 sectoral indices of NSE to investigate the significant impact of demonetization. Nifty 50 index and 10 sectoral indices represent the major sectors of Indian Stock Market.

\section{Objectives of the Study:}

The present study aims to achieve the following objectives: 
- To examine the impact of demonetization on Indian Stock Market.

- To evaluate the impact of demonetization on various sectoral indices in India.

\section{Research Methodology:}

The present study is focused on analyzing the impact of demonetization on Indian stock market. The study considers secondary data which has been extracted from the official website NSE, India. The period selected for the present study ranges from $15^{\text {th }}$ January 2016 to $29^{\text {th }}$ August 2017. For the present study, 200 days before and 200 days after the event of demonetization has been considered. The returns of the Nifty 50 index and 10 sectoral indices of NSE are computed with the help of daily closing prices. The closing prices are converted into log form for normality purpose. Dummy variables have been created for the study. The required analyses have been performed using the statistical software E-Views and MS Excel. To analyse the data statistical techniques has been used such as Graphical Analysis, Summary Statistics (i.e. Mean, Standard Deviation, Skewness, and Kurtosis), Unit Root Test and GARCH (Generalized AutoRegressive Conditional Heteroscedasticity) Model.

Augmented Unit Root tests have been used to check if data is stationary or non-stationary. The indices selected for study include Nifty 50, Nifty Auto, Nifty Financial Service, Nifty FMCG, Nifty IT, Nifty Media, Nifty Metal, Nifty Pharma, Nifty Private Bank, Nifty PSU Bank, and Nifty Realty Index. The present study utilized the GARCH model instead of event study methodology considering the edge GARCH model have over other models. A study performed the analysis by establishing dummy variables, and this is one more reason to use GARCH Model. Considering demonetization as an event, Stock Market Returns were taken as the dependent variable and the dummy variables as regressors. The study developed the necessary hypothesis to supplement the results in case of unit root testing (H0: There is unit root in data) and GARCH model (H0: There exist no significant impact of demonetization on Indian stock market). 
Patil, Parab \& Reddy | the Impact of Demonetization on the Indian Stock Market

\section{Results and Discussion:}

\subsection{Graphical Analysis:}

Figure 1
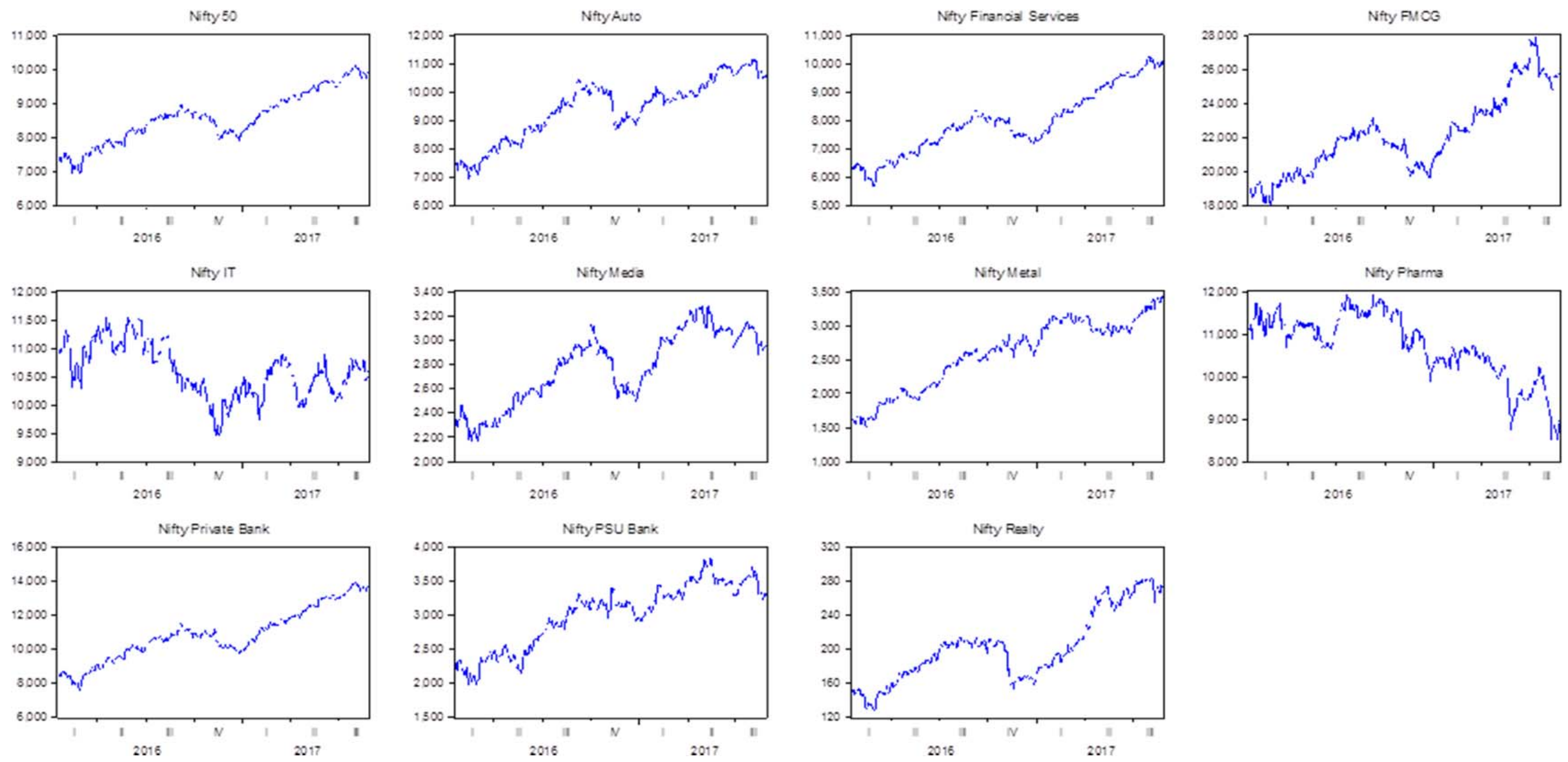

(Source: Compiled using E-views) 
The event of Demonetization was announced on $8^{\text {th }}$ November 2016. The above figure signified the effect of demonetisation on Nifty 50 index and 10 sectoral indices. The fluctuations are seen from the next day of the announcement on all the sectors except the Nifty Metal. Nifty Pharma has seen a tremendous downtrend. Nifty IT and Nifty Media have seen drastic downwards during the fourth quarter of the year. The effect of demonetisation was for a limited period after that index and indices slowly start rising except Nifty Pharma.

\subsection{Summary Statistics:}

Table 1

\begin{tabular}{|l|l|l|l|l|}
\hline Indices Returns & Mean & $\begin{array}{l}\text { Standard } \\
\text { Deviation }\end{array}$ & Skewness & Kurtosis \\
\hline Nifty 50 & 0.068851 & 0.809053 & -0.0663 & 4.770263 \\
\hline Nifty Auto & 0.082732 & 1.190169 & -0.25094 & 5.324522 \\
\hline Nifty Financial Services & 0.111764 & 1.007332 & 0.000824 & 4.475904 \\
\hline Nifty FMCG & 0.072596 & 1.107709 & -0.27512 & 8.046186 \\
\hline Nifty IT Index & -0.01137 & 1.038185 & -0.01786 & 4.965995 \\
\hline Nifty Media & 0.050556 & 1.333316 & -0.11771 & 4.44494 \\
\hline Nifty Metal & 0.183785 & 1.621782 & 0.270423 & 6.264714 \\
\hline Nifty Pharma & -0.05978 & 1.173737 & -0.19953 & 4.158996 \\
\hline Nifty Private & 0.117383 & 1.059106 & 0.096021 & 4.570579 \\
\hline Nifty PSU & 0.087332 & 2.011654 & 0.331392 & 5.794743 \\
\hline Nifty Realty & 0.140479 & 1.929753 & -0.8858 & 8.785608 \\
\hline
\end{tabular}

(Source: Compiled using E-views and MS Excel)

The above table shows the Mean, Standard deviation, Skewness, and Kurtosis for the selected dependent and independent variables. Mean measures the performance. The mean value of Nifty Metal Index is higher than the mean value of Nifty 50 Index, Nifty Auto Index, Nifty Financial Services Index, Nifty FMCG Index, Nifty IT Index, Nifty Media Index, Nifty Pharma Index, Nifty Private Bank Index, Nifty PSU Bank Index, and Nifty Realty Index.

Standard deviation measures the variations in the data. Lower the variation lower will be the standard deviation value and it is treated as favourable. From the above table, it can be seen that the Nifty 50 Index has the lowest standard deviation value.

Skewness measures the relationship between Mean, Median, and Mode.

a. When, Beta $(\beta)=0$ and Skewness is considered as Symmetry.

b. When, Beta $(\beta)>0$ and Skewness is considered as Positively Skewed. 
c. When, Beta $(\beta)<0$ and Skewness is considered as Negatively Skewed.

In the above table, the $\beta$ of Nifty Metal Index, Nifty Private Index, and Nifty PSU Bank Index is greater than 0 i.e., data is positively skewed. While the $\beta$ of Nifty 50 Index, Nifty Auto Index, Nifty FMCG Index, Nifty IT Index, Nifty Media Index, Nifty Pharma Index, and Nifty Realty Index is less than 0 i.e., the data is negatively skewed. Nifty Financial Services Index is equal to 0 , therefore, the data is Symmetrical.

Kurtosis measures whether the data is heavy-tailed or light tailed.

a. If the Beta $(\beta)=0$ or 3 , the data is considered to be Mesokurtic.

b. If the Beta $(\beta)>0$ or 3 , the data is considered to be Laptokurtic.

c. If the Beta $(\beta)<0$ or 3 , the data is considered to be Platykurtic.

In the above table, the $\beta$ of Nifty 50, Nifty Auto Index, Nifty Financial Services Index, Nifty FMCG Index, Nifty IT Index, Nifty Media Index, Nifty Metal Index, Nifty Pharma Index, Nifty Private Bank Index, Nifty PSU Bank Index, and Nifty Realty Index is more than 3, the data is considered to be Laptokurtic.

\subsection{Unit Root Test:}

Table 2

\begin{tabular}{|l|l|l|}
\hline Indices Returns & Augmented Dickey-Fuller test statistic & P-Value \\
\hline Nifty 50 & -18.59211 & $0.00^{* * *}$ \\
\hline Nifty Auto & -18.98595 & $0.00^{* * *}$ \\
\hline Nifty Financial & -17.60965 & $0.00^{* * *}$ \\
\hline Nifty FMCG & -19.41062 & $0.00^{* * *}$ \\
\hline Nifty IT & -18.76453 & $0.00^{* * *}$ \\
\hline Nifty Media & -20.39542 & $0.00^{* * *}$ \\
\hline Nifty Metal & -19.63185 & $0.00^{* * *}$ \\
\hline Nifty Pharma & -18.57986 & $0.00^{* * *}$ \\
\hline Nifty Private & -18.02345 & $0.00^{* * *}$ \\
\hline Nifty PSU & -20.08417 & $0.00^{* * *}$ \\
\hline Nifty Realty & -19.58970 & $0.00^{* * *}$ \\
\hline
\end{tabular}

(Source: Compiled using E-views and MS Excel)

Note: $* * * 1 \%$ level of significance 
The study performed unit root testing using Augmented Dickey-Fuller Test. The results as reflected in Table 2 indicate the data to be stationary as the null hypothesis gets rejected at $1 \%$ level of significance in case of Nifty 50 Index and the selected sectoral indices. The results are considered to be favourable in the context of the present study.

GARCH Model:

Table 3

\begin{tabular}{|l|l|l|l|l|}
\hline & Coefficient & Standard Error & Z-statistic & p-value \\
\hline Nifty 50 & -0.72910 & 0.151728 & -4.80534 & $0.0000^{* * *}$ \\
\hline Nifty Auto & -1.81420 & 0.293469 & -6.18191 & $0.0000^{* * *}$ \\
\hline Nifty Financial Services & -0.81171 & 0.203593 & -3.98695 & $0.0001^{* * *}$ \\
\hline Nifty FMCG & -0.97460 & 0.247038 & -3.94514 & $0.0001^{* * *}$ \\
\hline Nifty IT & -0.43038 & 0.235045 & -1.83104 & $0.0671^{*}$ \\
\hline Nifty Media & -1.11450 & 0.237918 & -4.68439 & $0.0000^{* * *}$ \\
\hline Nifty Metal & -0.04414 & 0.312085 & -0.14145 & 0.8875 \\
\hline Nifty Pharma & 0.26459 & 0.449762 & 0.58829 & 0.5563 \\
\hline Nifty Private & -0.79984 & 0.209834 & -3.81178 & $0.0001^{* * *}$ \\
\hline Nifty PSU Bank & 0.21618 & 0.410997 & 0.52600 & 0.5989 \\
\hline Nifty Realty & -3.47977 & 0.371353 & -9.3705 & $0.0000^{* * *}$ \\
\hline
\end{tabular}

(Source: Compiled using E-views and MS Excel)

Note: $* * * 1 \%$ level of significance, $* 10 \%$ level of significance.

The present study evaluates the impact of demonetisation on Indian stock market. For this purpose, this study implemented a GARCH model. The results are highlighted in Table 3 . The study noticed that in case of Nifty 50 Index, the null hypothesis gets rejected at $1 \%$ level of significance. Hence there exists a significant impact of demonetisation on Indian stock market. Such an impact was found to be negative. Similar results were obtained in the case of sectoral indices. The study evidenced a significant negative impact of demonetisation in case of Nifty Auto Index, Nifty Financial Services Index, Nifty FMCG Index, Nifty IT Index, Nifty Media Index, Nifty Private Bank Index, and Nifty Realty Index. The study found the Nifty Realty Index to be affected most because of demonetization 


\section{Conclusion}

Demonetization implies removing the flow of a specific currency from the economy and replacing it with the new currency. It is a process by which a series of currency will not remain a legal tender. The key objective behind demonetization was to eradicate corruption from India. The present study was focused on examining the impact of demonetisation on Indian Stock Market. The period selected for the present study ranged from $15^{\text {th }}$ January 2016 to $29^{\text {th }}$ August 2017. For the present study, 200 days before and 200 days after the event of demonetization had been considered. To analyse the data, statistical techniques have been used such as Graphical Analysis, Summary (i.e. Mean, Standard Deviation, Skewness, and Kurtosis), Augmented Dickey-Fuller Test and GARCH Model.

The results of the GARCH model indicated a significant impact of demonetisation on the Indian stock market. And such impact was found to be negative. Similar results were obtained in the case of sectoral indices. The study evidenced a significant negative impact of demonetisation in case of Nifty Auto Index, Nifty Financial Services Index, Nifty FMCG Index, Nifty IT Index, Nifty Media Index, Nifty Private Bank Index, and Nifty Realty Index. The Nifty Realty Index was found to be most affected because of demonetization.

The present study is useful for the government to examine the impact of demonetization on various sectors in India and thereby frame necessary policies. The study will contribute to academics and teaching as demonetization is a phenomenon which does not occur very frequently. A country demonetizes its currency with some special purpose. As Demonetization in India is of very recent origin, the academia can understand the impact of demonetization on the stock market through present study. Also study will help investors and other stock market participants for framing investment and trading strategies. There exists a scope for further research. The period of the study can be extended and volatility can be measured post demonetization.

\section{References}

Abda, S. (2017). Research Paper on Impact of Demonetization 2016 on Indian Economy. International Education \& Research Journal [IERJ], 3 (5), 580-581.

Betz, F., Anderson, T.R. and Puthanpura, A.K. (2017). Modeling Currency Flow in an Economy: The Case of India's Demonetization in 2016. Theoretical Economics Letters, 7, 1001-1014. https://doi.org/10.4236/tel.2017.74068.

Bhatnagar, A. (2017). Demonetization and Its Impacts in India. International Journal of Informative \& Futuristic Research, 4 (6), 6503-6510.

Bhausaheb N. V. (2017). A Study of Impact of Demonetisation in Indian Economy. Pune Research World- An international journal of interdisciplinary studies, 2 (1), 1-5.

Chelladurai, M. \& Sornaganesh, V. (2016). Demonetisation f Indian Currency and Its Impact on Business Environment. International Journal of Informative \& Futuristic Research, 4 (3), 5654-5662. 
Dharmapala, D. \& Khanna, V. S. (2017). Stock Market Reactions to India's 2016 Demonetization: Implications for Tax Evasion, Corruption, and Financial Constraints. Law and Economics Research Paper Series.

Gupta, A. (2017). A field study on the Impact of Demonetization Act on Disabled and their accessibility to Banks. New Man International Journal of Multidisciplinary Studies, 4 (3), 93-97.

Jain, R. (2017). Is Demonetisation a Windfall for the banking sector? Evidence from the Indian Stock Market. Economics Bulletin, 37 (2), 712-722.

Jaiswal, S. A. \& Jagtap, K. N. (2017). A Risk of Demonetisation and its Impact on Various Sectors. International Education \& Research Journal [IERJ], 3 (5), 511-513.

Kanakalatha, V. (2017). Emerging Issues and Challenges in Banking and Financial Services on Indian economy- Post Demonetization. International Journal of Advance Research, Ideas and Innovations in Technology, 3 (3), 1669-1673.

Nerkar, A. D. (2016). Demonetisation: Impact on Indian Economy. International Journal of Advanced Engineering Research and Science (IJAERS), 3 (12), 281-283. https://doi.org/10.22161/ijaers.3.12.50

Pradeep, S. (2017). Demonetisation in India \& its Effect on Growth. International Journal of Public Finance, Law \& Taxation, 2 (1), 31-42.

Rao, D. K. \& Kotian, R. R. (2017). A Study on Impact of Demonetisation of Currency Notes on the functioning of Indian Economy. J. Advances in Bus. Management, 3 (2), 99-101, DOI: $10.14260 / \mathrm{jadbm} / 2017 / 22$.

Samuel, Y. \& Saxena, A. K. (2017). A Study on Demonetisation and its Impact on Indian Economy. International Journal of Innovative Research and Advanced Studies (IJIRAS), 4 (2), 287-290.

Singh, D. B. \& Panwar, S. (2017). Study of Effects of Demonetization on the Informal Economy of India. International Conference on New Frontiers of Engineering, Science, Management and Humanities, 410-419.

Singh, P. \& Singh, V. (2016). Impact of Demonetization on Indian Economy. $3^{\text {rd }}$ International Conference on recent Innovations in Science, Technology, Management and Environment, 290-300.

Sinnarkar, T. J. (2017). Demonetisation in India and its Impact on Indian Banking \& Economic System. International Journal of Advanced Trends in Technology, Management \& Applied Science, 3 (5), 1-11.

Sivankutty, N, S. (2017). Impact of Demonetization on Gross Domestic Product (GDP) - An Analytical Approach. International Conference on Emerging Trends in Engineering, Science and Management, 1399-1404. 